\title{
A history of post-communist remembrance: from memory politics to the emergence of a field of anticommunism
}

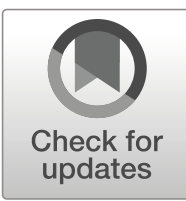

\section{Zoltan Dujisin ${ }^{1,2}$}

Published online: 8 July 2020

(C) The Author(s) 2020

\begin{abstract}
This article invites the view that the Europeanization of an antitotalitarian "collective memory" of communism reveals the emergence of a field of anticommunism. This transnational field is inextricably tied to the proliferation of state-sponsored and anticommunist memory institutes across Central and Eastern Europe (CEE), but cannot be treated as epiphenomenal to their propagation. The diffusion of bodies tasked with establishing the "true" history of communism reflects, first and foremost, a shift in the region's approach to its past, one driven by the right's frustration over an allegedly pervasive influence of former communist cliques. Memory institutes spread as the CEE right progressively perceives their emphasis on research and public education as a safer alternative to botched lustration processes. However, the field of anticommunism extends beyond diffusion by seeking to leverage the European Union institutional apparatus to generate previously unavailable forms of symbolic capital for anticommunist narratives. This results in an entirely different challenge, which requires reconciling of disparate ideological and national interests. In this article, I illustrate some of these nationally diverse, but internationally converging, trajectories of communist extrication from the vantage point of its main exponents: the anticommunist memory entrepreneurs, who are invariably found at the helm of memory institutes. Inhabiting the space around the political, historiographic, and Eurocratic fields, anticommunist entrepreneurs weave a complex web of alliances that ultimately help produce an autonomous field of anticommunism.
\end{abstract}

Keywords Collective memory $\cdot$ Field emergence $\cdot$ Field theory $\cdot$ Memory entrepreneurs · Memory politics $\cdot$ Post-communism

Zoltan Dujisin

Zoltan.dujisin@eshcc.eur.nl

1 ESHCC-Erasmus University Rotterdam, Burgemeester Oudlaan 50, 3062 PA Rotterdam, The Netherlands

2 Department of Sociology, Columbia University, 606 W 122nd St, New York, NY 10027, USA 
Embroiled in a cumbersome effort to come to terms with its Nazi past for decades, Europe is now haunted by the specter of a new memory. The Holocaust's singular standing as a negative founding formula of European integration, the culmination of long-standing efforts from prominent Western leaders (Levy 2010; Troebst 2010), is increasingly challenged by a memory of communism, which disputes its uniqueness. The Platform of European Memory and Conscience (henceforth Platform) conveyed this message in its exhibition "Totalitarianism in Europe: Fascism-Nazism-Communism," open between 2012 and 2016. The exhibit travelled to museums, memorials, foundations, city halls, parliaments, cultural centers, and universities in 15 European countries, stretching from Ireland to Romania, and was purported to "improve public awareness and education about the gravest crimes committed by the totalitarian dictatorships" (Platform 2013).

The exhibit's panels alternated between communist and Nazi "totalitarian crimes" in several countries, depicting war crimes, victims, the faces of perpetrators, and the number of condemnations. These numbers alerted the public to an alleged double standard between the justice given to victims of Nazi totalitarianism - epitomized by the Nuremberg trials - and those of communism. Affirming "a clear historical connection between Nazism and Communism," the organizers implicitly deem the entire communist experience grimmer, as it "continued to perpetrate international crimes ... until the very end of its existence." Furthermore, while claiming to mirror the "current state of knowledge, based on research in the countries presented" (Platform Platform 2012a), the exhibition mentioned none of the local drivers of communism, a burgeoning area of historiographic research.

The most prominent of the Platform's members - the state-sponsored and unwaveringly anticommunist memory institutes that have come to dominate memory-making in CEE - retrieved and interpreted the photographs and documents in the exhibition. Headed by political appointees and staffed with historians, memory institutes engage in a wide array of practices, including archival research, exhibits, teacher trainings, and lustration, stirring controversy along the way. The practices of these institutes are systematically embedded in an antitotalitarian conceptual universe, one that, their many critics claim, is inextricably linked to domestic political struggles. A link noticeable in the exhibit itself, which noted that "the consequences of terror ... last long after end of the regime" and include "widespread corruption and malfunctioning democratic institutions."

The panel exhibit occurred in the context of a string of EU-sponsored conferences, declarations, and commemorations reflecting the same antitotalitarian outlook. Most notably, in 2008, Members of the European Parliament (MEPs) passed a resolution establishing August 23 as the European Day of Remembrance for the victims of Stalinism and Nazism. This was the first time the EU opened the door to a potential equalization of communism and Nazism, a long-held view among conservative circles in CEE and beyond - and it was not the last. A 2009 European Parliament (EP) resolution on European Conscience and Totalitarianism called for "support for networking and cooperation among national research institutes specialising in the subject of totalitarian history" (European Parliament 2009a), in a clear reference to anticommunist memory institutes.

This article makes two key contributions. Empirically, it rejects a dominant interpretation of these events as a political expression of CEE's will to come to terms with 
its past (Kattago 2009; Leggewie 2010; Verovšek 2015), which one observer described as a moment of "post-EU accession ideological decolonization" (Mälksoo 2009, p. 656). Such accounts have failed to address the region's penchant for political instrumentalization of the past (Enyedi 2005; Mark 2010; Nalepa 2010), providing sound reason to marvel at post-communist elites' seeming articulation of a consensual regional message. A significant portion of the memory studies literature takes on the subject, thus reiterating a stubborn temptation to reify collective memory, that is, to confound the actual discursive manifestation of a narrative with the contingent social processes that sustain it. Unpacking these processes, this article argues that the postcommunist right's desire to complete an "unfinished revolution" (Mark 2010) drives the Europeanization of antitotalitarianism. The "unfinished revolution" concept relays the idea that communists retain a toxic and persisting influence over contemporary democratic institutions and that these communists should be removed from public life. These efforts, I shall argue, originate in the right's perception of a failed transitional justice, patent in the persistence of a former communist political left and of memory institutes as an adroit corrective. This corrective is not without substantial opposition, which forces its proponents constantly to carve new spaces of legitimation and autonomy. The creation of a European field of anticommunism is perhaps the most glaring example of this.

However, additionally, the case at hand invites theoretical reflection. Anticommunist memory institutes signal the rise of a novel power arrangement, one that regulates the transactions between politics and historiography, and which has diffused across the CEE region, particularly since the 2000s. This diffusion allowed for the emergence of a transnational exchange of knowledge, which accrued to the benefit of these institutes and refrained from interfering in their respective domestic prerogatives. Yet recent EU-level initiatives on antitotalitarianism have suggested a more complex story, one of a continuously evolving power arrangement entangling memory institutes, political elites, and MEPs from countries with idiosyncratic trajectories of communist extrication. By reconciling various oppositionsbetween nationalism and Europeanism, between liberalism and conservatismand by forcing an EU-wide reckoning with its official memory, this ensemble exhibits an autonomy and constitutive power that the mere sum of its components lacks. Bourdieu has posited fields as both bundles of relations (Bourdieu and Wacquant 1992, p. 97) and as spaces of struggle for autonomy and legitimation (Bourdieu 1996), producing effects by nature of their very structure, rather than as a result of simple mechanical aggregation (Wacquant 2016, pp. 16-17). Hence, I argue that we can best describe this power arrangement as a relatively autonomous field of anticommunism, one whose effects we must not infer from only the sum of its individual components, but from the multiple transactions and alliances that hold them together.

In consonance with this interpretation, I concentrate not only on the visible members of this transnational alliance, but additionally and especially on the brokers who sustain it, a species of memory entrepreneurs. Memory entrepreneurs have been defined as actors seeking social recognition and political legitimacy for their preferred narrative of the past (Jelin 2003, p. 33). In the post-communist context, this definition, which insufficiently explores the entrepreneurial dimension of the concept, encompasses much more than mere brokers. The term memory entrepreneurs does not apply to the 
prominent anticommunist dissidents of the 1990s, such as Václav Havel or Adam Michnik; or to the contemporary anticommunists who recurrently earn headlines in the Western press, such as Hungarian Prime Minister Viktor Orbán; and nor to pure academics, although memory entrepreneurs invariably possess scholarly qualifications. Rather, anticommunist memory entrepreneurs (henceforth anticommunist entrepreneurs) share commonalities with all the mentioned actors: With dissidents, they have a record of opposing "totalitarianism," but diverge from most liberal dissidents, who accept socialist successor parties as legitimate partners in the democratic game. With historians, they share a passion for gauging the past, albeit one primarily driven by a commitment to educating an apathetic public on the dangers of communism. In line with right-wing forces, they seek to exclude substantial portions of the left from power positions, although politicians' realistic compromises are a frequent source of disquiet. Anticommunist entrepreneurs' distinctiveness thus extends beyond a political ideology shared in wider circles. Rather, the term refers to a select group of actors whose biographies are spent shifting between politics and academia, equipping them with an "ability to keep multiple evaluative principles in play and to exploit the resulting friction of their interplay" (Stark 2009, p. 15). This translates to an aptitude to negotiate compromises between scholarly knowledge and political ideology, between historiographic practice and political action, and eventually between domestic demands and the exigencies of Europeanization. Their entrepreneurial singularity is most visible when they recombine resources from across these political, historiographic, and Eurocratic fields to generate innovative practices and unlikely alliances, all the while maintaining ideological coherence. Their contribution to post-communist memory politics thus lies in a penchant for accommodating just enough diversity and rallying just enough resources behind a common ideological goal.

This article focuses on four anticommunist entrepreneurs, each offering a hook to a distinct national or international trajectory: The late Janusz Kurtyka, former head of Poland's Institute of National Remembrance, and perhaps the most versatile of anticommunist entrepreneurs; Mária Schmidt, the perennial head of Hungary's Terror House, whose political clout is unmatched among her peers; Vladimir Tismăneanu, former head of the Institute for the Investigation of Communist Crimes in Romania, and academically the most prestigious of the group; and Neela Winkelmann, managing director of the Platform, whose cosmopolitan profile epitomizes the European turn of memory politics. By exploring their biographies and brokering practices, I aim to reveal how the national trajectories they represent have coalesced to form a field of anticommunism. While doing so, I reveal key power dynamics involved in discussions over the significance of communism in CEE: the dominance of antitotalitarianism, forms of resistance to it, the symbolic deficit of the left, and the partial cooptation of historiography. This article proceeds as follows: In the first part, I briefly consider how field theory can be applied to collective memory studies. Second, I offer an overview of my methods and case selection. Third, I trace the idiosyncrasies of the Polish, Hungarian, and Romanian trajectories of communist extrication. Fourth, I expand on the origins and consequences of anticommunist memory institutes' diffusion. Fifth, I assess the Europeanization of antitotalitarianism as a case of field emergence. The concluding section discusses the implications of this case, particularly for theorizing why fields emerge. 


\section{A field-theoretical approach to collective memory}

A detailed discussion of the collective memory concept falls beyond the purview of this article, however, a small number of considerations are required. I follow Olick in treating collective memory as "a wide variety of mnemonic products and practices" that represent different "moments in a dynamic process" (Olick 2006, p. 12) of societal negotiation and struggle for hegemony. This definition contrasts with popular - and frequently scholarly - understandings of "collective memory" as synonymous with "hard" identity, connoting sameness, group boundedness, and permanence across time and space (Brubaker and Cooper 2000, pp. 10-11). Thus, studies of memory politics have conflated collective memory as process and "collective memory" (henceforth with quotation marks) as identity. By differentiating between them, scholarly attention shifts to the processes and practices by which memory moves from struggle, contestation, and instability to a hard identity that projects sameness and permanence.

I suggest envisioning such struggles over definitions of "collective memory" as occurring in the context of Bourdieusian fields. Bourdieu's view of a social world driven by complex webs of relations, rather than direct causal lines, led him to replace the vague notion of "society" with the more concrete social topography of fields. He defines a field as "a network, or configuration, of objective relations between positions" (Bourdieu and Wacquant 1992, p. 97), which functions as an arena of struggle for specific prizes such as symbolic legitimacy and power. Fields are organized around specific types of capital, referring to species of power or dominance recognized as legitimate within the field (1992, p. 114). Typically, fields are defined by economic, cultural, social, and, of particular relevance for our purposes, symbolic capital, which designates informal but socially resonant and powerful categories of honor and prestige. This article operationalizes two forms of symbolic capital: 1) the symbolic capital of anticommunism, gained through an ability to portray oneself as having either fought the communist system as a dissident or its "remains" in post-communist politics; and 2) scientific capital, which refers to officially accredited forms of scientific and scholarly knowledge and resources that command authority. Capital possessions are central to determining an actor's field positions, however, the social practices observed within fields are not established simply by the said positions: Instead, movement within fields occurs as a result of an unconscious relationship between a habitus and a field (Bourdieu 1993, p. 76). Another central concept in Bourdieu's social theory, habitus, refers to the set of embodied and unconscious cultural dispositions that filter actors' perceptions of, and behaviors towards, the world. Fundamentally, habitus reflects a unique social trajectory, one that cannot be reduced to a "replica of a single social structure," but represents "a dynamic, multiscalar, and multilayered set of schemata subject to 'permanent revision' in practice" (Wacquant 2016, p. 64).

We can easily locate mnemonic struggles within fields as diverse as politics, the arts and journalism, all of which arguably furnish mechanisms of socialization into collective memory narratives. However, the preponderance of a given "collective memory" is less contingent on struggles in any given field than its overall societal resonance. While in relatively consensual societies resonance is continuously ensured by the reproduction of coherent structures of socialization, in less consensual settings, proponents of a narrative of the past may struggle to impose their narratives across fields. By way of illustration, politicians may make memory central to their political agendas, but will 
rarely overextend themselves by directly entering historiographic, journalistic, or artistic controversies. Their participation in such debates could easily be construed as illegitimate. A more effective approach consists in enlisting allies-historians, journalists, artists - whose position in their respective fields is perceived as legitimate to outsiders.

However, when memory struggles are distributed across fields, how does memory assume the semblance of an identity? How are the multiple mnemonic struggles occurring across fields amalgamated, negotiated, and re-adapted to produce the sort of coherence an identity demands? Field theory has only recently witnessed growth in interest regarding the issue of relationships between fields. As Bourdieu himself conceded to Wacquant, relations between fields do not seem to follow transhistoric laws (1992, p. 109), presupposing the latter to be governed by ad hoc orders. Eyal (2013) suggests these orders develop in an area of friction or overlap between fields where different temporalities, paces, and rhythms are somehow reconciled through sustained interaction. Envisioning such orders requires reconsidering the role of boundaries as lines that mark the end of one field and the beginning of another, and starting to treat them as the indispensable social entity they are: areas with enough volume to accommodate the struggles, flows, and exchanges between fields (Eyal 2013, p. 162).

In Eyal's view, these interstitial spaces generate mechanisms indispensable to the existence of fields as relatively bounded and coherent entities, while also allowing the mobilization of resources and alliances across them. This is the case particularly when massive social or cultural changes occur, during which the system of prevailing distinctions and classifications is disrupted and new social topographies may emerge (Eyal 2013, p. 179). As the literature shows, such topographies are often fields: In his appraisal of the origins of the French literary field, Bourdieu saw salons as "genuine articulations between the fields" of artists and politicians who discussed the distribution of material and symbolic rewards from the state (Bourdieu 1996, p. 51). This was a response to a sudden surge in secondary school diplomas during the early nineteenth century, with thousands of newcomers from the humanities unable to capitalize on their degrees and increasingly opting for literary professions. In the same vein, Steinmetz described colonial states as fields produced by the intersection of a colonial economic field and the metropolitan state, with the purpose of producing new governance and ethnographic practices (Steinmetz 2008, pp. 596, 602). Likewise, Medvetz (2012) traced the rise of a field of think-tanks to structural transformations propelled by the institutionalization of an academic, and later bureaucratic, field. Think-tanks would find a niche in the regulation of flows of knowledge and personnel at the crossroads of political, intellectual, economic, and media fields. The emergence of a field (henceforth field emergence) thus reflects an "effort to carve out some degree of autonomy from society-wide dominant powers" (Steinmetz 2011, p. 54) in the wake of momentous social transformations.

Organizational sociologists have weighed in on the debate, attempting to theorize field emergence beyond its mere structural preconditions. For instance, DiMaggio and Powell posited field emergence as a process of organic self-development driven by an increase in mutual interactions and a sense of common enterprise (DiMaggio and Powell 1983). However, organizational sociologists are generally wedded to a less agonistic and "micro" understanding of fields when compared to Bourdieu's, who emphasizes conflict and complexity. Yet the former have long alerted analysts to the 
role of entrepreneurship in producing novel social arrangements through the recombination of existing elements, suggesting the sort of translation and recombinant practices Eyal expected to find in the spaces between fields. For instance, Fligstein argued that field emergence is driven by "skilled social actors" (Fligstein 2001) entrusted with translating existing rules via persuasion, cooperation, and accommodation of other groups to produce compromise identities and local orders. More recently, Stark defined entrepreneurs as actors with an "ability to keep multiple evaluative principles in play and to exploit the resulting friction of their interplay" (Stark 2009, p. 15). Both contributions help us envision entrepreneurs as generative actors who operate across fields and are comfortable mobilizing their respective "evaluative principles." However, both also fall short of accounting for how entrepreneurs come to possess these recombinant skills.

I draw three preliminary conclusions from this brief discussion on field emergence: First, as Marin and Gregg (Martin and Gregg 2015, p. 52) point out, our difficulty in studying fields as delimited and bounded realities requires a "de-emphasis on the study 'of' fields as entities in favor of an exploration of fundamental field theoretical processes" as the one revealed by the problematic of field emergence. Second, a friction between social orders, caused by a transformation in the social structure, must occur for any kind of interstitial space to "thicken" its boundaries; it is from here that fields may emerge. Third, this "space between fields" must be willfully exploited by actors who recruit allies, translate interests, and convert and exchange the capitals they bring into play. The remainder of this article attempts to account for the mechanisms of field emergence by engaging with both structural preconditions and an agency grounded in habitus, all the while showing structure and agency interconnection through practice. This account is grounded in Bourdieu's social theory, therefore, the hypothesized field of anticommunism must be tested against the features of a Bourdieusian field, understood as $^{1}$ : a) a space of mutual recognition in which actors oriented towards a common function engage in both contest and cooperation. This proceeds from the fact that a) "all the agents that are involved in a field share a certain number of fundamental interests, namely everything that is linked to the very existence of the field," leading to "an objective complicity which underlies all the antagonisms" (Bourdieu 1993, p. 73); b) These interlocking antagonisms then give way to a "competition among different forms of competence, at once hostile and complementary" (Bourdieu 1986, p. 821), producing a field-specific division of labor; c) a dominant capital or combination thereof towards which actors orient their struggles, establish hierarchies, and define legitimate forms of expertise; d) a desire for autonomy from overpowering societal forces, and since processes of autonomization tend to be "accompanied by an increase in the standards expected of anyone seeking right of entry to the field (Bourdieu 1991, p. 177), e) fieldspecific membership rules that function as more or less institutionalized "barriers to entry" (Bourdieu and Wacquant 1992, p. 100).

\section{Methods and case selection}

Data was gathered through prosopography, in-depth interviews, and documentary sources. Between November 2012 and May 2014, I conducted a total of 38 interviews

\footnotetext{
${ }^{1}$ The bold italics will help reiterate these features through the empirical data in the fifth section.
} 
with anticommunist entrepreneurs and historiographic and other scholarly experts. Against the background of historical analysis, their subjective and often contradictory accounts of the relations among the fields they inhabit were pieced together to approximate their objective structure. This picture was complemented with documentary sources, including cooperation agreements, mission statements, organigrams, and project descriptions, retrieved directly from 11 memory institutes as well as the Platform. An additional batch of documents was obtained from EU sources: Official declarations on the Union's historical legacy, EP debate transcripts on European memory, and EP public hearing reports and presidency programs. Finally, I deployed elite prosopography (Stone 1971) to reveal the biographies and field positions of four anticommunist entrepreneurs, whose data we obtained by consulting curriculum vitae and biographical webpages and through the conducting of elite interviews.

The four anticommunist entrepreneurs selected represent encompassing national trajectories of communist extrication, while offering a hook to their eventual accommodation in a European setting. The Hungarian, Polish, Romanian, and Czech/ Europeanization trajectories were chosen due to their influence at the EU level-they are the most populous post-communist nations in the EU. Furthermore, the cases shared commonalities, such as frustration with transitional justice, and persistence of the postcommunist left, as well as peculiarities - state commissions in Romania, the creation of the anticommunist memory institute model in Poland, a dissident tradition in foreign policy in the Czech Republic. In summary, each national trajectory offered a palette of shared and contrasting interests and sensitivities that allowed for exploration of the challenges and nuances of their reconciliation in a European space.

\section{Post-communist transitional justice}

CEE is united by a shared experience of state socialism and a dominant desire for European integration, but the paths from the former (very diverse state socialist regimes) to the latter (privatization and increasing convergence to EU standards) had distinct shapes. Romania, one of the most repressive state socialist regimes, was the scene of a violent revolution, while Czechoslovakia had a peaceful one, whereas in Poland and Hungary, communist doctrinaire leaders gave way to a technocratic class before the transition, and this same group proved pivotal in facilitating economic and political reform. Within post-communist political fields, understood as domestic arenas of struggle for power and legitimation, the collapse of state socialism introduced the theme of a "return to Europe." Imposing an overriding concern to comply with EU political and economic standards (its acquis communautaire), this theme provided a direction to a disoriented polity, but simultaneously reduced space for programmatic differentiation. Emphasis was thus redirected to a symbolic/identitarian dimension, where struggles to monopolize the symbolic capital of anticommunism became increasingly central to political struggle, shaping and fracturing politics to this day (Bernhard and Kubik 2014).

Anticommunism was more than an identity on which to legitimize the political fields that emerged from the ashes of communist regimes - it was a prolongation of antitotalitarian frameworks developed by both liberal and conservative dissident movements in the 1970s. For both groups, populated by a substantial number of historians and 
other intellectuals, labelling communist regimes as "totalitarian" helped draw a clear line between the regime and the opposition, in order to mobilize the population. There was little agreement beyond this pragmatic compromise, with liberals advocating human rights and civic patriotism and conservatives underscoring nationalism and "national memory" as repertoires of resistance (Kopeček 2012, p. 590). Persuaded that totalitarianism offered an inaccurate portrayal of everyday life under communismdespite its political utility - most liberal dissidents came to modify the notion to convey the supposed totalitarian ambitions, rather than power, of communist elites (Brier 2011, p. 204). Many political formations of post-communism would emerge out of these dissident communities of intellectuals, furthering a traditional blurring of the lines between politics and scholarship in the region.

Three principal positions emerged with regard to the thorny issue of transitional justice: a (left-) liberal stance, inspired by calls on citizens to assess introspectively their own role in reproducing communist power (Michnik and Havel 1993); an occasionally liberal, though more often conservative antitotalitarianism that drew a sharp line between victims and perpetrators; and a modernizing/third-way socialdemocratic outlook that found a focus on the past unproductive and, less explicitly, acknowledged communism's mixed heritage. Attempts to deliver transitional justice in post-communism were invariably coopted by political competition between these groups, causing popular exhaustion with memory politics and ultimately laying the foundation for the appearance of anticommunist memory institutes (henceforth memory institutes).

\section{Poland}

The Polish transition offers a paradigmatic case of negotiated transition, whereby liberal and conservative dissidents, led by the Solidarity opposition trade union, sat down with reformist communist party officials to negotiate a change of regime. The latter successfully sidelined communist hardliners before entering negotiations with the opposition over transitioning to a democratic institutional framework.

As became increasingly clear, the negotiated nature of transition did little to quell resentment among those who saw representatives of the old regime as unduly profiting from the ensuing privatization of state assets. While regime opponents had informally agreed to forgive and draw a "thick line" to mark off the communist past, liberal and conservative parties quickly adopted anticommunist political identities. As early as 1992, a liberal-conservative coalition government promoted press leaks of a list of 64 supposed former agents remaining in parliament or government. The unsubstantiated nature of the list sparked an outcry that led to the resignation of Jan Olszewski's government, as well as calls to regulate lustration. In 1993, Social Democracy of the Republic of Poland (SdRP), the successor of the Polish United Worker's Party, won the parliamentary elections following a decline in living standards caused by market reforms. In the years thereafter, the right-wing opposition would ride popular resentment against SdRP, which had profited from leasing communist-party-owned buildings to private enterprises and from partial privatization of its media empire (Hashim 2002, pp. 43-47). 
In 1997, with the left still in government, parliament agreed on a lustration law that allowed for vetting commissions in various important sectors of public life. Lustration laws were mild, leading at most to public shaming, but never outright dismissal, yet among former opponents of the communist regime, many were becoming wary of the process. Prominent liberal dissident Adam Michnik claimed that, as a result of lustration, "[p]eople who worked in the communist-era bureaucracy, even if they committed no crime, are penalized because of an affiliation with others higher up in the leadership" (Michnik and Dulzin 2002, p. 519). However, among the most dissatisfied with the state of affairs was a group of conservative, Solidarity-affiliated dissidents who began calling for a new institution that would reenergize the process of communist extrication. In 1998, following a heated parliamentary debate, the Institute of National Remembrance (IPN) was born, inheriting staff, archives, and other infrastructure from the Central Commission for the Investigation of German Crimes in Poland, a body created during communism to prosecute crimes committed in the course of the Second World War.

While the memory institute's promoters gained inspiration from the German Stasi Records Agency (BStU) strictly tasked with assessing the role of East Germany's secret police, IPN was given the broader responsibility of managing national historical memory, namely by prosecuting communist and Nazi "crimes against the Polish nation," classifying and regulating access to communist-era files, and producing academic research for public education purposes. The institute's prosecutorial powers triggered sustained opposition, not only from the former communist left, but from liberal daily Gazeta Wyborcza and its editor in chief, Michnik. Liberal intellectuals warned that rather than regulate lustration, the institute would turn it into an instrument of revenge against representatives of the former regime, although criticism waned after a group of IPN historians played a prominent role in investigating Polish participation in the Holocaust. However, those fearing politicization were vindicated after the electoral victory of the conservative Law and Justice (PiS) party in 2005 and the election of anticommunist entrepreneur Janusz Kurtyka as head of IPN.

PiS had embraced the narrative of an "unfinished revolution." The communist successor party, now called the Democratic Left Alliance, remained influential, having elected President Aleksander Kwaśniewski for two consecutive terms $(1995,2000)$. PiS repeatedly claimed communists had captured the Polish state, and promised to cleanse the country of hidden communist networks, adopting the line of communism as inherently evil and anti-Polish. The party's campaign represented an attempt to monopolize the symbolic capital of anticommunism: PiS could argue that they had not compromised with communists, having played a minor role in the 1989 round-table negotiations, while its relatively younger ranks were less likely to have collaborated with the former regime. Crucially, PiS would find a strong ally in IPN, where many historians shared their diagnosis of the country and perceived their role in politically proactive terms:

Communists, and I mean communists, are still a very influential group in all of our countries ... there are branches of the economy that are stuffed with former secret service officials: the banking system, telecommunications, energy transfer 
... they have influence in the media, newspapers, it is difficult to fight it. (E. Michalski, personal communication, January 2013)

Kurtyka's appointment as IPN president heralded the institution's embrace of a conception of history and politics as inevitably intertwined, effectively thickening the space between the political and historiographic fields. With a political formation that dates to his opposition activism in the 1980s, involving anything from distributing leaflets to clandestine radio transmissions, Kurtyka was more than a historian. Wishing to raise political awareness by popularizing history, Kurtyka contributed to clandestine publications as a doctoral student at the Institute of History of Sciences in Warsaw and later offered underground lectures on World War II and post-War history. In postcommunism, he obtained a doctoral degree from the Institute of History of the Polish Academy of Sciences, after which he completed a postdoctoral degree from Jagiellonian University and joined the Scientific Council of the Academy. His postcommunist trajectory is no less connected to politics: throughout the 1990s, he joined various conservative parties and, in 1993, ran for Parliament for the Catholic Electoral Committee. During this time, Kurtyka developed strong ties with veteran organizations, lobbying state officials to fund their publications, decorate their representatives, and establish commemorations to honor veterans (Musiał 2012).

His versatility was largely responsible for, and amply evident prior to, his appointment as IPN President, as he was appointed director of IPN's Krakow branch in 1998. Using negotiating skills and contacts unavailable to most historians, Kurtyka offered researchers and public educators access to previously unavailable archival documentation from communist-era police, courts, prisons, and other state and local authorities. Often acting autonomously from IPN headquarter wishes, his branch was also the first in the country to establish an electronic inventory for outside researchers. Kurtyka clearly prioritized the Krakow Public Education Office, which was the only IPN structure to create a publication series independently from Warsaw, as well as the first to organize an outdoor exhibit. Furthermore, his branch created training centers and teaching aids for teachers, a practice followed by memory institutes throughout the region to this day, and concluded a cooperation agreement with various media, most notably the conservative daily Dziennik, where IPN historians were granted a weekly column (Musiał 2012). As a former IPN colleague of Kurtyka's notes, the emphasis he pushed on public education was not to be taken for granted at that time:

In the original idea it was not expected that research and public education would expand so significantly ... the idea was to put the archives outside political control into an independent institution. In the law the educational research activities is only in one article, whereas the investigation of files, archives, occupy chapters of the bill. But the research and education branch expanded to become as big as the other branches, and in the public and the media this became more visible. (Krzysztof Persak, p.c. 2013)

Kurtyka's ideological commitment, as well as his entrepreneurial ability to diffuse a coherent message across fields, led him to the Presidency of IPN, in a move that also certified the institution's political vulnerability. Having been elected by a board of 11 
members voted by Parliament, of which only one was of the opposition, ${ }^{2}$ Kurtyka was free to purge IPN's central positions. As the former director of IPN's Bureau of Public Education notes, this resulted in an influx of politically proactive historians who profoundly changed the institution:

Kurtyka supported a new group of historians and archivists who identified themselves with the political and historical line of PiS. There was an alliance and cooperation between PiS and Kurtyka, and this had great influence on books published, conferences organized, this new line had several meanings, a greater focus on exposing people who were presumably agents of the communist security apparatus and were active in public life. (Paweł Machcewicz, p.c. 2013)

A harsher lustration law, passed in 2007, would make IPN responsible for lustration, in what was perhaps the last gasp of a prosecutorial approach to the past in Poland. Kurtyka had relaxed regulations for media access to archives and had ultimately encouraged IPN historians to denounce anyone suspected of harboring ties to the former regime. This had been a source of controversial, unregulated leaks in the past - a trend epitomized by the accusations against former dissident and Polish President Lech Wałęsa (Nalepa 2010, pp. 17-19). However, the new lustration law soon encountered trouble, with the judiciary deeming key articles of it unconstitutional, thereby rendering it largely ineffectual. Research and public education would henceforth dominate public perception of the institute's activities, which remains an object of regional envy among anticommunist entrepreneurs to this day, with 2500 historians, $80 \mathrm{~km}$ of archives, and 1000 educational projects yearly (Łukasz Michalski, p.c. 2013).

In a testament to his proximity to political power, Kurtyka died in April 2010 after the presidential plane in which he travelled with then Polish President Lech Kaczyński and several other high-level officials crashed on its way to a ceremony in Smolensk, Russia. For anticommunist entrepreneurs, his legacy would set a powerful "vision" and a "building block" (Winkelmann, p.c. 2012) for the ensuing Europeanization of antitotalitarianism.

\section{Hungary}

Hungary was home to the least repressive regime among the four under examination. The most traumatic event of communist rule occurred in 1956, when Warsaw Pact troops entered Hungarian territory to quash an anti-Soviet popular revolt, causing thousands of casualties. As in Poland, the transition was negotiated between reformist communists and dissidents, leading to the rapid reintegration of the communist successor party in the country's democratic life. While lustration targeted former communist-era officials and collaborators, laws were relatively mild, leading to public shaming at most, particularly as the political right feared being equally compromised by a harsher approach. Lustration became widely perceived as a mere political weapon and

\footnotetext{
${ }^{2}$ This law was amended in 2010 , to allow leading universities and history departments to propose the candidates that parliament may subsequently consider for the board.
} 
a distraction from economic mismanagement and failed reform (Kiss 2006, p. 927), and memory politics quickly assumed purely symbolic undertones.

In particular, 1956 would become symbolic of many of the political battles of postcommunism: the event was pivotal to the political birth of Viktor Orbán, not only a key figure in the politicization of anticommunism, but a participant in its history. Hungary's most successful politician, with four terms as prime minister (1998-2002; 2010present), Orbán introduced himself to the world as the liberal leader of the Fidesz opposition movement in 1989, when Hungary's reformist socialist regime allowed him to speak at the ceremonial reburial of communist revolutionary leader Imre Nagy. Nagy had been executed in 1958 and was condemned as a counter-revolutionary for decades, yet in 1989, authorities agreed to rehabilitate his image with a reburial. His funeral gave Orbán a chance to stake his anticommunist credentials in front of a huge crowd: While communist leaders were clearly moving the country in a democratic direction, Orbán accused them of failing young generations and said they deserve no gratitude (Csipke 2011, p. 100).

His performance impressed many, not least Mária Schmidt, the region's most enduring anticommunist entrepreneur: "I was always anticommunist. I first 'fell in love' with Orbán in 1989 when he gave his speech.... It was the most important speech of that era in Hungary.... I said, 'Oh my God, he's the bomb!'” (McMahon 2019). Having graduated in history and German literature before the regime change, Schmidt became assistant professor in history at the Pázmány Péter Catholic University in 1996. With Orbán's 1998 election, she moved to politics, to become his chief advisor, a position that would earn her the nickname of Orbán's "court historian" and allow her to assist Fidesz's voyage from a liberal to a conservative party. Her entry into politics did not signal an abandonment of academia: In 1999, within a year of her new advisory position, Schmidt received a $\mathrm{PhD}$ in history, which allowed her to become an associate professor at her university and a full professor by 2010 .

Schmidt's embrace by Fidesz culminated the party's ideological shift on every key issue except anticommunism, which was expressed in an uncompromising stance towards the socialists (Enyedi 2005). The advantages of this strategy were not always obvious. In a familiar story for the region, in 1990, Hungarians elected the conservative Hungarian Democratic Forum to conduct painful economic reforms, causing a dramatic decrease in living standards. The Hungarian Socialist Party (MSZP) capitalized on this dissatisfaction to refashion itself as a competent and pro-European party of economic managers, and thereafter returned to power, starting in the mid-1990s (Bozoki and Ishiyama 2002, p. 5). As with the Polish left, the party was populated by former communist-era managers who, unlike the old communist cadres that disappeared from public life, had clearly benefited from privatization (Eyal et al. 1997). Their insider status posed a double bind, allowing socialists to claim "ideology-free" economic expertise, but also constituting a tacit acknowledgment of complicity with the defunct regime. Regardless, their modernizing message appealed to otherwise anticommunist liberals with whom the socialists would form a governing alliance in 1994. This development gave conservative anticommunists the opportunity to redefine Hungarian politics as a struggle between true anticommunists and regime accomplices: "the Liberals, who pretended to be Anticommunist and then switched sides, we will never forgive them. You never forgive traitors," was Schmidt's crude analysis of that momentous event (McMahon 2019). 
After winning the 1998 election, Fidesz would begin blurring the space between the political and historiographic fields, relocating resources away from academic research institutes to new research bodies widely perceived as politicized. With Schmidt as chief advisor, the government moved to defund two independent research institutes: The Institute of Political History (defunded by HUF 50 million, roughly USD 230,000 at the time) and the Institute for the Research of 1956 (by HUF 67 million). The latter had long been a target of conservative criticism, as its liberal historians stood accused of overemphasizing leftist and reform communist participants in the revolution (Kiss 2015 , p. 248). The sums were reallocated to the newly founded Public Foundation for the Research of Central and Eastern Europe, headed by Schmidt herself. From within this foundation three formally distinct institutions were created: The twentieth Century Institute, the twenty-first Century Institute, and the Terror House Museum, all of which saw Schmidt appointed director general (Hamvay 2015).

While Hungary inherited several institutions and scholars from a relatively autonomous communist-era historiography field, elsewhere in the region, the cash-stripped sector proved vulnerable to the prevailing zeitgeist or to outright cooptation. The 1990s brought about a dismissal of communist era scholarship and embracing of a positivist and fact-collecting orientation, justified in terms of emancipation from ideological control (Ferenc Laczó, p.c. 2013). This empowered a subgroup of right-wing historians intent on depicting "Hungarian history as a general success story occasionally interrupted by ... intrusions from "outside" (Trencsényi and Apor 2007, p. 45). Its younger members in particular were relatively isolated from the methodological mainstream of the discipline, but saw this isolation as a result of leftist, communist-era biases. Together with other junior historians struggling to find employment in history departments, these conservative youngsters provided the backbone for Schmidt's politics of history (Péter Apor, p.c. 2013).

The Terror House, firmly controlled by Schmidt, would rise as the crown jewel of an institutional apparatus reconciling political and historical practice, and as the largest and best endowed museum of communism in the region. Orbán delivered the inaugural opening speech outside the museum building, in what seemed like a campaign event. The Terror House was shutting the door on a "long and sad $20^{\text {th }}$ century at the last minute." Orbán declared to the crowds six weeks ahead of the 2002 election that he would lose to the socialists: "At the last minute because it threatened to continue" (Berrnuli 2002).

The museum's building, previously used by the Hungarian national socialists and later by the communist secret police, conveys continuity between fascism and communism: Visitors are guided through its cellars, interrogation rooms, and gallows, where both Nazis and communists tortured and executed political prisoners. While putatively concerned with all forms of totalitarianism, all but two of the museum's two dozen rooms are dedicated to communism. Upon entering, visitors are welcomed by a "wall of perpetrators" depicting photographs of former communist leaders and secret agents, many of them the fathers of contemporary liberal politicians. Thereby, present and past are once again connected.

The Terror House, which meanwhile became the object of ritualistic excursions for school children around the country, infuriated socialists and liberals, who toyed with the idea of renaming it the "House of Reconciliation." However, the left ultimately opted for a $40 \%$ slash to the museum's funding, to which a confident Schmidt 
responded by threatening to close the museum, forcing socialist Péter Medgyessy to backtrack. Schmidt's confidence is revealing:

130,000 people came to the opening of the Terror House, if they try to overhaul it or close it down then they will have again 130,000 or more come here, and they [the leftists] do not want that, because anyway they have a legitimation problem. (Mária Schmidt, p.c., May 2013)

Moreover, the prime minister agreed to provide subsidies from his own allocation to the museum, which he effectively legitimated through an official visit (Kiss 2015, p. 248), and the socialists would relinquish all ambitions to change the composition of the museum's foundation board (Hamvay 2015).

Medgyessi's about-face tells a larger story of the left's symbolic vulnerability in the region. While the socialists have occasionally invoked their role in initiating the transition from what was already a "reformist" regime, their attempts to formulate a historical narrative were negligible prior to the political irruption of Ferenc Gyurcsány. Having joined the socialist government in 2002 as an advisor, by 2004 Gyurcsány was attempting to tackle the past head-on with the manifesto "Dare to be on the left." In his manifesto, he attacked the right's fear of modernity and its allegedly authoritarian (and anti-Semitic) interwar nostalgia, contrasting it with the left's continual reformism. The text was not well received, as Gyurcsány's biography contained every element that confirmed the right's view that regime change had compensated, rather than punished, communists: A former President of the Organization of Young Communists, Gyurcsány successfully pursued a career in the private sector during the 1990s, and by 2002, was among the fifty richest people in Hungary (Origo 2002). His next attempt to tackle the past, following his 2006 election as prime minister, had to be more conciliatory, and began with a crucial acknowledgment: both left and right had skeletons in their closets - and the left had consistently attempted to link the right to an authoritarian threat, but the memory of communism was indeed fresher. The essay, titled "Confrontation," not only admitted the left's symbolic deficit, but made no attempt to salvage any positive features of the regime, such as its unprecedented social mobility and modernization drive (Kiss 2015, pp. 249-255).

While victorious in the 2002 and 2006 parliamentary elections, the past would come back to haunt the socialists. In a leaked recording of a private party meeting released shortly before the fiftieth anniversary of the 1956 revolution, Gyurcsány admitted lying about the country's crumbling finances to ensure the 2006 re-election. For many on the right, the prime minister had lied and tampered with the election just as the communists had routinely done in the past. For an entire month, Budapest witnessed the worst episodes of violence since 1956, with protesters demanding Gyurcsány's resignation. As the country plunged into the worst legitimacy crisis of post-communism, protesters successfully recreated some of the key moments of the 1956 rebellion. Most notably, hundreds of angry rioters broke into the Hungarian state television headquarters, demanding the broadcast of a nationalist manifesto - much in the same way the 1956 revolutionaries had occupied the Hungarian state radio headquarters to demand autonomy from Soviet rule. 
While Gyurcsány only resigned in 2009 , to be replaced by a caretaker government, Orbán would use the time leading up to the 2010 election to appropriate the symbolic capital of 1956 and drive a stake through the socialists' legitimacy. Schmidt, by then board chairman of Hungary's media union and an active media commentator, put all her weight as a historian behind the strategy, widening the resonance of the unfinished revolution narrative:

"The party-state elite was not replaced when the regime changed. The socialistliberal coalition ... restored the power positions of the old elite of state-run operators, beneficiaries and servants within the government and the public sector ... Twenty years after the regime change, the old communist elite holds almost every key position." (Schmidt 2009).

In 2010, Orbán would win his so-called "revolution in the ballot box," with an unprecedented two-thirds majority, on the promise to rid the country of the remaining traces of its communist past. In 2013, Fidesz would create an additional two memory institutes that began eroding Schmidt's monopoly on memory-making: the Veritas Historical Research Institute, the Research Institute and Archives for the Study of the Regime Change, and the Committee of National Remembrance.

\section{Romania}

Nicolae Ceauşescu's reclusive and nationalist regime, lasting from 1965 until his execution in 1989, was terminated by a violent revolution that brought about a semipresidential democracy. The new regime barely promoted transitional justice measures, apart from a hasty removal of communist statues and symbols, with no prosecutions for crimes committed under the previous regime. Lustration laws, passed several times, were seldom implemented and repeatedly declared unconstitutional (Horne 2017, p. 101), whereas the settling of political scores drove informal attempts at lustration. State structures, political parties, and a significant portion of the population have consistently opposed a prosecutorial approach to the past (Tănăsoiu 2008, p. 89): as recently as $2010,78 \%$ of Romanians did not even think they or their families had suffered under communism (Iacob 2015, p. 417).

However, there has been no lack of transitional justice demands. The revolution witnessed the rapid emergence of the National Salvation Front (NSF), a group comprising mostly systemic insiders who initially presented themselves as a supra-partisan collective. The NSF's self-labeling was rejected by a self-styled "democratic opposition," a combination of nationalist conservatives and civic liberals who refused any compromise with forces associated with the past (Tănăsoiu 2008, pp. 83-84). Instead, they advocated an immediate recovery of the nation's memory, namely through demands to reveal Securitate (secret police) files and implement a three-legislature ban of all former communist activists and officials. However, in May 1990, voters effectively rejected this agenda by electing NSF head Ion Iliescu as president. A former communist who would serve three terms (1990-1992, 1992-1996, and 2000-2004), Iliescu would establish himself as a towering figure in Romanian politics. 
Iliescu's opponents have persistently insinuated that his personal biography is at the root of a pervasive "state amnesia" regarding communism (Stan and Tismăneanu 2015, pp. 26-27). Head of the propaganda department in the 1960s, Iliescu fell out with Ceauşescu in the 1970s, continuing to serve at the county level without openly opposing the regime. His opponents saw this period, described as "punishment" by Iliescu, as an unforgivable show of allegiance to the regime - although only a handful of Romanians had engaged in oppositional activity. Their belief in Iliescu's complicity with communism became pivotal to the liberal conservatives' strategy for the 2000 presidential election. Iliescu hoped to regain power following the presidency of liberal Emil Constantinescu (1997-2000) who, tellingly, had done little to confront the past himself. Despite official enquiries into Iliescu's activities as county leader and alleged Securitate collaborator, state archives failed to corroborate the opposition's accusations, and Iliescu won the election (Stan 2002, p. 57).

Iliescu's return to power was a blow to liberal conservatives, who advocated confronting the past. Romania's best-known scholar, Vladimir Tismăneanu, would rise as the most prominent voice among them. Better known to Western academic audiences as a professor of political science at the University of Maryland and former editor of the peer-reviewed journal East European Politics and Societies, Tismăneanu simultaneously pursued various forays into politics. Born into a family of underground communists - his father fought in the Spanish Civil War and became chair of the Marxist-Leninism department at Bucharest University-Tismăneanu endorsed both the regime and reformist Marxist ideas as a graduate student and student leader. However, his family's deteriorating political position eventually created obstacles to his career, precipitating his decision to leave an increasingly repressive Romania. Ultimately settling in the United States at the height of the Reaganite Cold War in 1982, Tismăneanu dropped his neo-Marxist leanings and gained recognition as an expert on Romanian matters in both media and academic circles. During the 1980s, he was appointed at the Foreign Policy Research Institute and the University of Pennsylvania, while relentlessly attacking Ceausescu's regime from platforms such as Radio Free Europe (Poenaru 2013, pp. 113, 127).

Post-communism would catapult Tismăneanu into the role of liberal conservative opinion maker in Romania, a country he believed had "shunned the vital historical soul-searching needed for a real national therapy" (Tismăneanu Tismaneanu 1993, p. 310). Iliescu, having recognized communism as a failed utopia, refused to attribute Romania's structural problems to the existence of former communist networks. In contrast, liberal conservatives believed precisely those networks, symbolized by Iliescu's continuing power, were responsible for the failure of post-1989 reforms, which were perceived as "cosmetic, minimal, always in danger of being reversed by the former communist ruling elite" (Tănăsoiu 2008, p. 85).

Tismăneanu's much-awaited opportunity to usher in a national "soul searching" would come following the victory of liberal conservative Traian Băsescu in the 2004 presidential election. A former low-ranking member of the communist apparatus, who lacked any dissident pedigree, Băsescu sought to refashion himself as an anticommunist. In 2005, his conservative coalition partners had been responsible for establishing the Institute for the Investigation of Communist Crimes (IICMER). With one-third of the parliament composed of prominent communist-era figures, Băsescu was keen on 
avoiding lustration ${ }^{3}$ and instead opted for creating the Presidential Commission for the Study of the Communist Dictatorship in Romania, entrusting it with an official and "scientific" assessment of the communist past (Ciobanu 2009, p. 333). The commission and the memory institute represented rival attempts to monopolize the symbolic capital of anticommunism, but crucially, Băsescu named Tismăneanu as commission head to bolster his initiative's scientific legitimacy.

Albeit not a historian himself, Tismăneanu (Tismaneanu 2003) was instrumental in shaping Romanian historiography, owing to his interpretation of Romania's regime as "National-Stalinist." The field was generally weak, with research on the communist period consisting mainly of diaries, memoirs, oral history interviews, or assortments of documents, which revealed a lack of knowledge regarding the treatment of sources, little interest in theoretical and methodological issues, and inclination for event-based political history (Petrescu and Petrescu 2007, pp. 319, 365, 370-371). This resulted in a crude positivism whereby scholars explained the regime's survival on the basis of police brutality, while omitting "legitimate sources of power, their movements, and their evolutions" (Laignel-Lavastine 2004, p. 162).

As head of the commission, Tismăneanu selected nineteen members on merit of either their scholarly qualifications or, more importantly, their commitment to anticommunism. This was the case for Nicolae Manolescu, a leading liberal politician and literary critic who, as a student of philology in the 1960s, was expelled from Bucharest University for criticizing the regime. The commission also included eighteen remunerated experts who, in another boost to the commission's scientific capital, were given unprecedented access to previously restricted archives.

During a rowdy parliamentary session that included swearing, booing, and the waving of banners, Basescu presented the 700-page document as providing a scientific basis to condemn communism. The report offered an insight into an antitotalitarian approach that has remained prevalent in Romanian historiography. The regime is characterized as Stalinist from the beginning to the end, with party ideology manipulating every aspect of citizens' lives. All aspects of regime repression were examined, mostly at the expense of revealing its social bases of perpetuation (Iacob 2015, pp. 438$439,454)$. The report also externalized communism as "antipatriotic ... totally surrendered to Moscow and hostile to national political and cultural values." Furthermore, the commission's report ensured past and present were connected: It claimed communism fell "only officially" in 1989, positing that its structures, methods, and mentalities "continued to exist under different guises, some extremely pernicious" (Tileaga Tileagă 2012, pp. 467, 472). The text made 28 references to Iliescu, including in a short biography accompanied by those of other apparatchiks, and accused him of "cultivating methods similar to those practiced by communists, the demonization of civil society and democratic parties, symbolic manipulation, unscrupulous propaganda" with the intent "to strangle the frail pluralism born on December 1989" (cf. Hogea 2010, p. 23).

A subsequent controversy, during which critics accused Tismăneanu of using his influence on editors to suppress criticism of the report (Hyperliteratura 2013), is illustrative of his growing influence at the time. Several left-leaning figures, among them historian

\footnotetext{
${ }^{3}$ A recent investigation by the National Council for the Study of Securitate Archives, CNSAS, found Băsescu to have been a Securitate informer and collaborator - a decision upheld by a Romanian court (Gascón Barberá 2019).
} 
Michael Shafir and former conservativepolitician Daniel Barbu, compiled the most prominent critique of the report in 2008, titled The Illusion of Anticommunism. Its authors accused the commission of factual inaccuracies, conceptual leaps, and an overemphasis on intellectuals. Furthermore, they directly attacked Tismăneanu for ignoring criticism from peers while engaging with easily rebuttable reproaches originating in the far right. Despite Illusions being authored by previously published, established authors, no publishing house in Romania would circulate the book, which was finally released in neighboring Moldova (Poenaru 2013, pp. 145-156). Responding to the accusations, Tismăneanu would reaffirm the scientific primacy of archives, noting that Illusions "did not rely on any archival research and engaged in an ideological, not scholarly, critique" (Stan and Tismăneanu 2015, p. 35).

In 2010, Tismăneanu was appointed head of IICMER, the hitherto rival initiative to the commission where, in line with regional trends, he would pursue a strictly scholarly and educational approach to anticommunism: If, in previous years, the memory institute had consistently, but unsuccessfully pushed for prosecuting possible communist crimes, Tismăneanu veered it towards implementing commission recommendations. For instance, IICMER produced an elective high school history textbook and launched websites on topics such as Ceauşescu's politics of reproduction, biographies of the nomenklatura, and Iliescu-suppressed miner protests. In an intimation of what was to come, Tismăneanu also cited his report as "Romania's contribution to the creation of a collective, transnational memory of the crimes of communism in a united Europe" (Stan and Tismăneanu 2015, p. 31), becoming an active participant in the Europeanization of antitotalitarianism.

\section{From diffusion to Europeanization}

Memory institutes found fertile ground in regions with a shared history of communism and of blurred lines between politics and the intelligentsia, popping up, with varying degrees of political and financial support, virtually everywhere from Estonia to Albania and Ukraine. Their ubiquitousness raises two questions, the first of which can be posed in terms of their diffusion: how did it occur and what was so new and unprecedented that made these memory institutes politically appealing? The second question, which flows from the first, asks what kind of power arrangement was brought about by this diffusion.

As the outlined cases show, the paths leading to the creation of memory institutes, while distinctive, have consistently been grounded in variants of the "unfinished revolution" narrative, one that has engaged numerous communities of historians. However, the novelty of these institutes cannot be reduced to the creation of a space between politics and historiography, as such spaces obviously predate their conception. Instead, memory institutes came to be perceived as valuable instruments to regulate the overlapping space between the political and historiographic fields. Direct and constant politicization of memory, so characteristic of the 1990s, had produced popular fatigue and, in the case of lustration, proven politically risky, precipitating the normalization of socialist parties. Memory institutes helped solve this dilemma: struggles over the meaning of the past persist in the public imagination, but the political right disavows direct responsibility for their perseverance; instead, it is now often assumed by memory institutes. This arrangement has successfully excluded many critics of the state-sponsored narrative; critics whose limitations emanate from the structure of the fields they navigate. In the political field, communist 
successor parties remain symbolically crippled and their criticism easily dismissed as selfserving, whereas liberals have lived in fear of aligning too closely with reviled "former communists." Within underfunded historiographic fields, scholars remain vulnerable to cooptation, with only the most scientifically autonomous and prestigious being able occasionally to voice public criticism.

Pivotal to this arrangement are anticommunist entrepreneurs, who connect the interests of previously disconnected actors by overseeing capital exchanges; the most important of which sees scholars grant scientific legitimacy to the narratives of political elites in exchange for higher salaries, greater public visibility, or access to archival sources. Political elites, on their part, obtain scholarly validation for their "unfinished revolution," outsourcing a central dimension of political competition onto institutions that promise a monopoly on the symbolic capital of anticommunism. The specific set of abilities that anticommunist entrepreneurs contribute, which require reaching and connecting disparate actors in order to sustain a coherent message across fields, has thus been pivotal to the viability of the power arrangement represented by memory institutes. As the biographies of Kurtyka, Schmidt, and Tismăneanu have shown, this skillset is rooted in a hybrid habitus, rather than being an innate gift - a habitus formed through a professional trajectory spent in various fields relevant to memory making. As anticommunist entrepreneur Andreja Valič Zver, director of Slovenia's memory institute, put it:

I worked many years in schools and in faculties, I know the educational area, I know what is in history textbooks, and this helps a lot. I also was very much involved, and still am, in history teachers' projects, associations, I know what their problems are when it comes to dealing with totalitarian regimes and crimes. Then at the level of historiography I am the author of history textbooks, monographies, articles. We always have to evaluate our work and question ourselves in the field of historiography. Then there are judiciary issues, we need to study judiciary methods, this is where the political contacts are important, these levels are always living in a kind of political environment, they are mingled with politics. (p.c. 2012)

Considering the idiosyncrasies of national political, judicial, educational, and historiographic fields, memory institutes have proven remarkably malleable. The BStU in Germany provided a first source of inspiration for politicians, activists, and historians who sought responses to the heated topic of handling secret police archives (Hans Altendorf, p.c. 2013), but it would be Poland's IPN that would inadvertently serve as a laboratory of best and worst practices for keen regional observers. The IPN's strong prosecutorial profile and lustration prerogatives had invited accusations of political targeting and careless archival work, from which anticommunist entrepreneurs drew the lesson that combining lustration with historical research was politically sensitive (Pavel Žáček, p.c. 2012). From this point onwards, memory institutes no longer thrive in a relatively isolated national setting, but develop with increasing awareness of the experiences and knowledge accumulated by peers elsewhere.

As governments established successive memory institutes throughout the 2000s, focus progressively shifted onto research and public education, with an ever-growing pool of "lessons" and "experiences" for newcomers such as Romania's IICMER (2005) to experiment with: 
We needed the expertise of other institutions ... we were more interested in public education, they [Czechs, Germans, and Lithuanians] were making summer schools, contests and trainings for children, educational materials, somehow we started looking at what they are doing and we started doing similar things ... [From Lithuania we took] a contest for children with essays about what communism meant, there were thousands of essays, and three years later we went to Budapest and a historian told us the communists were doing the same thing, the children will look in the books and bring you the official history as is written now ... this is not the way to do this and we stopped this. (Raluca Grosescu, p.c. 2013)

Such formal and informal exchanges engendered a tight milieu of historians and public educators, who increasingly met under the aegis of memory institute-sponsored events. Particularly important was the 2005 IPN conference, "The Communist Security Apparatus in East Central Europe 1944/45 to 1989," which brought 350 participants to Warsaw at a time when only six memory institutes existed:

This conference was influential in the way of thinking in other countries, it provided some patterns to be followed. But creating such institutes required political positions. We offered some modus operandi to follow, some examples ... Contacts can start informally between historians, and they are brought to the institutional level. The milieu of historians researching the secret police is not so big, we know each other from conferences and other events ... when we meet it turns out we have very similar problems, the reaction to our activities is quite similar: problems with public opinion, reactions to the opening of files, so we have very common and similar experiences which integrate us. (Krzysztof Persak, p.c., January 2013)

This transnational network of historians was pivotal to the establishment of the European Network of Official Authorities in Charge of the Secret Police Files in 2008. The network was established to provide members, including strictly archival state institutions, with mutual archival access, opportunities for joint research, and a knowledge pool of public education practices. By the late 2000s, what had begun as a loose and informal community was thus giving way to an institutionalized network.

The 2004 EU accession of eight post-communist countries would begin to affect this arrangement, with anticommunist entrepreneurs increasingly persuaded that the Europeanization of antitotalitarianism held the potential to provide further legitimation and umbrage to their cause. Diffusion had served its purpose: memory institutes had benefited from a common knowledge bank without interfering in each other's "national backyards." EU accession was about something else.

Europeanization is a process of political integration by which social fields become detached from their close links to the central institutions of the nation-state and are reoriented towards a new European entity (Schmidt-Wellenburg 2017, p. 437). The tension here is obvious: Europeanization required memory institutes to reorient their allegiances partially from previously overriding, domestic discourses to a new common goal, one calling for deepened cooperation and a laborious discursive streamlining. Examples of potential sources of friction abound. While in both Romania and Hungary 
the theme of an "unfinished revolution" was key to political competition, this narrative had liberal backing in Romania, which was unthinkable in the Hungarian context. Moreover, in the small Baltic nations, anticommunism rarely implied a hidden clique, instead expressing opposition to Russian influence on its populous minorities, usually in the form of communist-era "mental schemes" (Ronaldas Račinskas, p.c. 2013). Reconciling these multiple sources of friction required a novel power arrangement, one that is best described as a relatively autonomous field.

\section{Europeanization as field emergence}

The Eurocratic field incorporates all actors dedicated to European integration and the functioning of EU institutions (EP, European Council, lobbyists, etc.). Their actions have been described in terms of multiple, cumulative compromises that gradually establish a common frame of ideals, procedures, historical references and political culture (Georgakakis and Rowell 2013, pp. 3-6). Anticommunist entrepreneurs' efforts in this field had two principal dimensions: Firstly, by leveraging many of the institutional mechanisms deployed by their Western precursors in enshrining a European memory of the Holocaust, they sought an EU-level condemnation of communism; secondly, by establishing an institutional foothold in the European Union through the Platform of European Memory and Conscience, they engendered novel, joint practices - such as the travelling exhibit - that aimed to protect their institutes from domestic political contingency. Crucially, they found a conjuncture that was ripe for an EU-wide reckoning with communism. In 2007, the European Union approved a law against Holocaust denial just as the twentieth anniversary of the fall of the Berlin Wall approached. Post-communist countries demanded provisions against the denial of "communist crimes" in vain, but successfully compelled EU justice commissioner Franco Frattini to organize a public hearing on Stalin-era crimes, thereby introducing the topic of Nazi-communist equivalence into the EU agenda (Rees 2010, p. 231). More importantly, a favorable political constellation yielded the support of the rotating EU presidencies ${ }^{4}$ of Slovenia (2008), Czech Republic (2009), Hungary (2011), and Poland (2011). Friendly governments were at the helm of all four presidencies, while their temporal proximity proved decisive to a sustained intervention deep into the Eurocratic field.

The Czech Republic assumed a leading role in these initiatives. An active and transnationally oriented dissident community had occupied a prominent space in the country's politics, being overrepresented within the foreign policy establishment (Waisová and Piknerová 2012). Among many transitional justice measures, former dissidents were additionally responsible for establishing the Institute for the Study of Totalitarian Regimes (USTR). Created in 2007, the Czech memory institute immediately assumed an internationalist orientation, often by the hand of anticommunist entrepreneur Neela Winkelmann. While less connected to historiography proper than her peers, her political, civic, and academic experience, as well as her knowledge of

\footnotetext{
${ }^{4}$ The Rotating Presidency of the Council of the EU changes every six months, among EU member states, and is responsible for directing the agenda and operations of the Council of the EU, the upper house of its legislature.
} 
foreign languages, catapulted her to this transnational endeavor. The granddaughter of Jaroslav Heyrovsky, the 1959 recipient of the Nobel prize in chemistry, Winkelmann spent her life moving among Czechoslovakia, Germany, India, Malaysia, and the United States, where, in 1997, she earned a $\mathrm{PhD}$ in molecular biology at Cornell University. An environmental activist in the 1980s and a member of the Academic Senate of Charles University's Faculty of Sciences between 1990 and 1992, she was appointed head of the Green Party's energy section and subsequently ran as their candidate for the 2004 EP elections. In the following years, she would serve Senator Martin Mejstř́k (2005-2008), a former anticommunist dissident, 1989 student leader, and one of the drafters of the law establishing the USTR.

Once appointed as USTR's project coordinator, Winkelmann began a conscious effort to relocate transitional justice efforts away from a frustrating domestic realm and onto a European "playing field":

All these constraints we have here [Czech Republic], the judiciary that doesn't work, the communists in parliament, it was clear for us we need to ... achieve a European understanding that communism is as despicable as Nazism and it should be condemned internationally.... we tried all kinds of approaches, we met victims of the regime, we had political meetings, we had legislative initiatives that never succeeded, we spoke to students at schools ... we realized this is a new dimension that enables us to create our own new playing field at the European level ... we have all been hitting obstacles so much on our local turf that this is our new playground. (N. Winkelmann, p.c. December 2012)

Winkelmann's plan to elude domestic political contingency was easily aligned with the interests of key actors located in the Eurocracy. Friendly EU presidencies hungry for content and topics offered memory institute historians the chance to come to Brussels to present in conferences and public hearings on totalitarianism as part of their presidency agendas. ${ }^{5}$ MEPs rich in symbolic capital gained through anticommunist dissidence, such as László Tökés, Vytautas Landsbergis, and Sandra Kalniete, shared the memory institutes' commitment to an EP resolution on Nazi and communist crimes, and expressed interest in the scholarly legitimation they could provide.

In 2011 the cooperation between MEPs and anticommunist entrepreneurs gave way to a distinct division of labor, expressed in a dual organizational structure: With a supportive resolution from the EP and funding from the EC and various postcommunist states, Winkelmann formed the Platform as a Brussels-based umbrella organization for memory institutes. Simultaneously, approximately forty MEPs joined forces to set up the informal parliamentary grouping "Reconciliations of European Histories" and promote the antitotalitarian agenda on the EP level. This dual structure once again projected anticommunist entrepreneurs into an interstitial zone, where they facilitate exchanges among domestic political patronage, historians, and now also presidencies and MEPs in the Eurocratic field. For these European actors, memory

\footnotetext{
${ }^{5}$ Friendly EU Presidencies have organized several similar events, with titles such as "Crimes Committed by Totalitarian Regimes," "European Conscience and Crimes of Totalitarian Communism," and "What do Young Europeans know about Totalitarianisms?"
} 
institutes have become "basically their think tank, we are their scholars, their legitimation for their political demands, because when it comes from us it is justified, it has a backing" (Winkelmann, p.c. 2012). Further, anticommunist entrepreneurs' intermediate position within this new division of labor reveals the dominant capitals structuring the field of anticommunism: on the one hand, MEPs anti-communist symbolic capital holds considerable sway and prestige, also outside field boundaries. Undoubtedly, its holders represent the powerful faction of the field. However, as Winkelmann highlighted, this symbolic capital requires "backing," precisely what memory institute historians provide through their scientific capital. Forging networks that reach into politics, academia, and the Eurocracy, and mobilizing them into struggles against "communism," anticommunist entrepreneurs occupy a central, if relatively anonymous, position in the field by possessing both capitals and, crucially, through their ability to exchange and combine them.

The setup of a cross-sectoral and transnational alliance was, however, anything but spontaneous, requiring a strenuous discursive streamlining symptomatic of a space of mutual recognition, contest, and cooperation. In the wake of the "European Conscience and Communism" conference hosted by the Czech senate in June 2008, six months before the country would take the rotating EU presidency, anticommunist entrepreneurs and leading anticommunist politicians jointly drafted the Prague Declaration (2008). Its naming implicitly paid homage to the 1985 Prague Declaration, sent by pro-European Czech dissidents to a peace congress in Amsterdam. While the 1985 variant called for a united, demilitarized Europe (Waisová and Piknerová 2012, p. 170), the 2008 declaration similarly demanded a united Europe, only this time founded on the recognition of communist and Nazi ideologies as "inseparable." Specifically, the declaration advocated an international day of remembrance for the victims of both regimes, continent-wide parliamentary acknowledgment of "Communist crimes as crimes against humanity," and an "adjustment and overhaul of European history textbooks." In a significant symbolic victory, organizers secured the support of one of the greatest figures of liberal anticommunist resistance worldwide, Václav Havel. His signature not only signaled liberals' abdication to a conservative-inspired antitotalitarianism, but buttressed anticommunist entrepreneurs' claims to represent the will of the region.

However, Havel's endorsement proved insufficient to stifle dissent in what was a relatively heterogeneous alliance. The Prague declaration's call for "scientific and educational" approaches to the memory of communism led Tismăneanu to term it as "the fulfillment of the second stage of post-communist development" (2010, p. 133), however, many natural allies refused to endorse it publicly. On the one hand, conservative hard-liners like Schmidt found the declaration "did not emphasize enough the crimes of communism" (p.c. May 2013). On the other, a group of pragmatic anticommunist entrepreneurs feared the text's many parallels between communism and Nazism would alienate potential partners dealing with Holocaust memory, whose enlisting was key to securing funding from the Europe for Citizens Program, the EU's only mechanism dedicated to commemorative projects (Littoz-Monnet 2012, p. 1195). In the words of a Lithuanian anticommunist entrepreneur, the parallels were "wrong

\footnotetext{
${ }^{6}$ The first draft was prepared by Swedish conservative politician Göran Lindblad, formerly in the Council of Europe, and Mejstř́k, with contributions from Winkelmann and Tismăneanu (Raluca Grosescu, p.c. 2013).
} 
tactically, it's shooting one in the foot, giving arguments to opponents.... We are losing very strong and very important support from Jewish and Holocaust research circles who would not accept this equalization" (Ronaldas Račinskas, p.c. 2013).

Tensions flared again during negotiations over the agreement establishing the Platform as an umbrella organization for memory institutes and their allies. Winkelmann successfully retained the totalitarian terminology favored by conservatives against the concerns of several liberal-minded scholars, who had to concede the term, with all its flaws, "rings a bell with the public" (Bogdan Iacob, p.c. February 2013). However, due to pressure from the Czech Ministry of Foreign Affairs and pragmatic partners such as Germany's BStU, the document strayed from the Prague declaration by underscoring the "exceptionality and uniqueness of the Holocaust." Conservatives met the allusion with "a huge uproar: people were saying 'why should we mention the Holocaust' or 'if we mention the Holocaust we have to mention the Gulag." Schmidt reportedly lamented the agreement: "I am so ashamed. I have my Prime Minister [Orbán] ... tomorrow I am going home and have to explain why [I signed this]" (Bogdan Iacob, p.c. 2013).

The episode reveals the Platform's relatively autonomous position between the Eurocracy and domestic political fields, each prescribing its respective interests, yet without fully imposing them: Domestic political fields require memory institute sponsors to push antitotalitarianism in a bid to delegitimize the former communist left, a strategy that implicitly calls the exceptionality of Nazism into question by equating it to communism. In contrast, Holocaust uniqueness is a guiding principle of the Eurocratic field, and recognition of this uniqueness remains a prerequisite for obtaining logistical and financial support outside narrow post-communist circles. The formal upholding of both antitotalitarianism and Holocaust uniqueness failed to satisfy fully either liberals or conservatives, but Schmidt's dissatisfaction is particularly telling of a momentous shift in the region's memory politics: The most visible face of Hungary's powerful memory regime, one assembled on the Terror House's communist-Nazi equivalence, had failed her prime minister and bowed to pressure from a relatively autonomous European center.

The balancing acts between liberalism and conservatism, nationalism and Europeanization, and scholarship and political activism, remain effective. Composed of sixtytwo members, including memory institutes, private foundations, and NGOs, the Platform has become the governing structure of an autonomous field of anticommunism. Autonomy is secured particularly via EU and other external funding, ${ }^{7}$ with the Platform either pooling resources for common projects - such as an "anti-totalitarian reader" to be used as a teaching aid-or helping members coordinate applications. While the Europe for Citizens program has consistently privileged Holocaust-related projects, memory institutes' involvement in legally binding transnational projects limits hostile governments' potential to shut them down. Conversely, projects' adherence to EU standards circumscribes any friendly cabinet's ability to politicize their domestic implementation (Bogdan Iacob, p.c. 2013).

The Platform's ability to enlist EU allies — and thus increase the autonomy of the field it governs - is, however, curtailed by both internal and external forces. Internally,

\footnotetext{
${ }^{7}$ Other organizations that have supported memory institute projects include USAID, British Council and the Konrad Adenauer Foundation.
} 
the platform's code of ethics has established a set of explicit membership criteria, most notably that its members do "not knowingly employ ... former functionaries with paid political jobs in totalitarian political structures" (Platform 2012ab). The criterion led to the suspension of the leading force behind the Platform's creation, the Czech memory institute, which was accused of being "infiltrated by Communist collaborators" due to leadership changes ordained by a newly elected leftist senate (Platform 2014). These acts of "purification" underscore the Platform's principled operation, one that contrasts with politics' porousness to immoral and opportunistic compromises with "communists."

Externally, the Platform is often perceived as overtly political, and its upholding of Holocaust uniqueness insincere. A failed attempt by the Federal Foundation for the Reappraisal of the SED (East German) Dictatorship to join the Platform provides a telling account of the limits for contestation imposed by the field, a field whose representatives periodically define through practice "the common interests underlying conflicts of interest" as well as "all the undiscussed and unthought areas tacitly kept outside the limits of the struggle" (Bourdieu 1975, p. 34):

It was obvious that their real interest was with the communist past, and that they were only interested in taking Nazism and WWII into their research institutes to justify the comparison. [They] tend to argue that taking Soviet and Asian communism together it has more victims than National Socialism and thus is in a way more evil.... We felt it was kind of a usurpation of history and of dealing with history. Not in a consensual way, but just to follow your political tasks.... They were not happy about what we said and they don't invite us anymore. (Ulrich Mählert, p.c. 2013)

Previously, the EP resolution on European conscience and totalitarianism had triggered the most discernable critique of the antitotalitarian coalition in Europe. In one of the competing motions that preceded the resolution's adoption, Socialist MEPs argued that "official political interpretations of historical facts should not be imposed by means of majority decisions of parliaments." Further, the MEPs noted that "20th century history of Europe is very complex and ambivalent, as are people's memories of it" (European Parliament 2009b). While the latter amendment was not adopted in the final version, the socialists were successful in including various warnings against the political instrumentalization of history, while simultaneously replacing the terminology of "communist" with "Stalinist" crimes (European Parliament 2009a). However, even the final version was displeasing to several Socialists MEPs. In the words of British MEP Glyn Ford, the resolution included "elements of a historical revisionism that flies in the face of a demand for objective analysis" and "threatens to dilute the unique nature of the Nazi crimes" (European Parliament 2009c).

However, none of these outlined concerns seems to have gained political traction. A September 2019 EP resolution on the importance of European Remembrance for the future of Europe, while still referencing Holocaust uniqueness, contained various references to "crimes of totalitarian Communist regimes." In addition, it directly blamed the Nazi-Soviet Molotov-Ribbentrop Pact for the outbreak of World War II, in line with the historiography advanced by memory institutes, and it called for greater 
EU support for the activities of the Platform. Ultimately, anticommunist entrepreneurs seem to have been favored by renewed concerns among liberals and conservatives related to Russia's influence in Europe. The resolution denounced Russian efforts to "distort historical facts and whitewash crimes committed by the Soviet totalitarian regime," which have been deemed "a dangerous component of the information war waged against democratic Europe that aims to divide Europe." Most significantly, the declaration failed to call for any caution against the political instrumentalization of the past, as had been the case in 2009 (European Parliament 2019).

\section{Conclusion}

This article shows that the various national trajectories of communist extrication and recent efforts to Europeanize an antitotalitarian "collective memory" are more entangled than had been previously claimed. This entanglement has its origins in the 2000s, when anticommunist entrepreneurs, a group of committed anticommunists who straddle the boundary between politics and academia, converged on the need for a "revolution" that would unseat powerful and hidden "former communist" networks. Faced with the need to mobilize a relatively indifferent public, anticommunist entrepreneurs proposed a public education offensive in the form of memory institutes. The symbolic capital of anticommunism, previously up for grabs in the political field, is now regulated and apportioned by institutions that seek to legitimate scientifically the "unfinished revolution." By occupying the interstitial space between politics and historiography, memory institutes thus created a "thick boundary," a space of transactions and alliances that has nonetheless lacked the autonomy and oppositions that typify a field.

The diffusion of memory institutes did not considerably alter this social topography, that is, until anticommunist entrepreneurs began identifying opportunities to rework the existing power arrangement through EU membership. If, in the past, anticommunist entrepreneurs were only accountable to their domestic political patrons, they could now play the contradictory pulls of the Eurocratic field and domestic politics off each other. While driven by a shared goal of a European condemnation of communism, the need to organize these pulls, translated into ideological (liberal vs conservative) and tactical ("Holocaust uniqueness" versus "totalitarianism") oppositions, provided the fundamental impulse for field emergence-one that, over time, has produced autonomous governing bodies, a distinct division of labor between holders of anti-communist and holders of scientific capital, and specific membership rules.

While the field of anticommunism imposes sacrifices and compromises on its members, its power to retain them lies on the promise of a scientific and "European" legitimation for antitotalitarianism: With every symbolic victory at the European level, every regional show of unity, every step towards a homogenized narrative, communism is reaffirmed as totalitarian, as unchanging in time and space, inclusive of its "covert," post-communist incarnations. By extension, the already fragmented domestic resistance to antitotalitarianism, whether by liberals, social democrats, or historians, is "provincialized" in the face of a European consensus. Hence why, even under this new arrangement, politicians 
have every incentive to reduce political control while maintaining material, political, and logistical support for memory institutes; after all, the legitimacy of their principal product, scientific capital, rests on an ideal of autonomy, one that now finds validation in "Europe."

By leveraging the hybrid professional trajectories of anticommunist entrepreneurs, this article identifies the prerequisites for field emergence in the linkage between structure and practice. Following field theorists, field emergence is temporally situated in the wake of a momentous historical transformation (the transition from state socialism and accession to the EU) and topographically located interstitial spaces (the thick boundaries among politics, historiography, and the Eurocracy). Following organizational sociologists, the article offers insights into the recombinant abilities of (in this case, anticommunist memory) entrepreneurs, whose competence in merging political, historiographic, and Eurocratic practice fulfills the generative potential of the interstitial spaces they occupy. Their trajectories highlight, on the one hand, anticommunist entrepreneurs' ability to create novel power arrangements, and on the other, the grounding of their entrepreneurial abilities, not in some innate skills, but in a hybrid habitus that reflects their position in the social structure. This is not to claim these skills are structurally given, but merely to highlight that some degree of overlap between their hybrid professional trajectories and the social structure is likely a prerequisite for these entrepreneurial skills to transpire. In describing the dynamics of emergence of the French literary field, Bourdieu noted its early protagonists became aware of a "political conjuncture which, grasped through the categories of perception inherent in their dispositions, allows and encourages their inclination to independence (Bourdieu 1996, p. 60).Schmidt, Kurtyka, Tismăneanu, and Winkelmann share a disposition shaped by their constant navigation of field intersections; what makes them exceptional is their ability to exploit that unique habitus in their common quest for autonomy: by balancing the contradictory pulls of political discourse and scholarly production, by reconciling the imperatives of domestic politics with the quest for scientific and European legitimation, all the while exploiting, rather than succumbing, to these frictions. Their generative balancing act is what the emergence of a field of anticommunism ultimately encapsulates.

Future research on field emergence would do well to examine its potentially hybrid protagonists, not out of an ontological affirmation of the primacy of agency, but as a hook from which to fathom the structural transformations and contradictions from which fields emerge. One promising line of inquiry would be transnational fields, such as the one described here, created to produce the sort of autonomy that a "thick boundary" lacks. Rather than involving a functional reformulation at the level of the interests, practices, or actors operating in the spaces traditionally occupied by memory institutes, the field of anticommunism offers a "vertical" autonomy that extends the geographical scope of interactions. This extension occurs by fusing the resources produced by various national and dependent interstitial spaces, reattracting them to a new geographical level (Europe) without fundamentally altering the modality of "domestic" practices. In other words, the field's innovation is not to be sought at a functionally different sphere of practice, but rather at a distinct 
geographical level within the same practice sphere (Buchholz 2016, pp. 41-42). With the growing availability of transnational spaces as relief valves from domestic limitations, one can expect transnational fields to emerge according to similar patterns, whereby practices and actors are fundamentally preserved, yet empowered by a geographical upscaling.

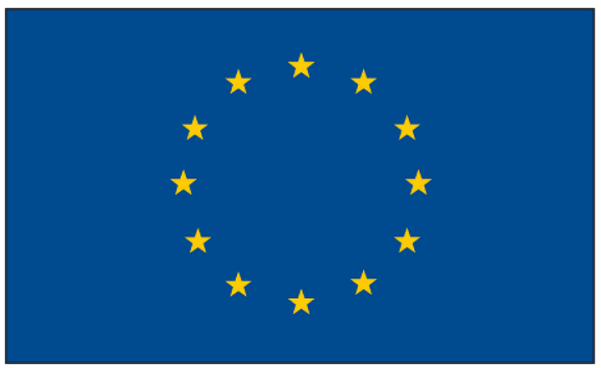

Funding This article has received funding from the European Union's Horizon 2020 research and innovation program under the Marie Skłodowska-Curie grant agreement No. 707404. The opinions expressed in this document reflect only the author's view. The European Commission is not responsible for any use that may be made of the information it contains.

Open Access This article is licensed under a Creative Commons Attribution 4.0 International License, which permits use, sharing, adaptation, distribution and reproduction in any medium or format, as long as you give appropriate credit to the original author(s) and the source, provide a link to the Creative Commons licence, and indicate if changes were made. The images or other third party material in this article are included in the article's Creative Commons licence, unless indicated otherwise in a credit line to the material. If material is not included in the article's Creative Commons licence and your intended use is not permitted by statutory regulation or exceeds the permitted use, you will need to obtain permission directly from the copyright holder. To view a copy of this licence, visit http://creativecommons.org/licenses/by/4.0/.

\section{References}

Bernhard, M. H., \& Kubik, J. (2014). Twenty years after communism: The politics of memory and commemoration. Oxford: Oxford University Press.

Berrnuli. (2002). Orbán Viktor megnyitja a Terror Háza Múzeumot 2002-ben. https://youtu.be/DAQpHYU3 $\mathrm{m} 3 \mathrm{~s}$

Bourdieu, P. (1975). The specificity of the scientific field and the social conditions of the progress of reason. Information (International Social Science Council), 14(6), 19-47.

Bourdieu, P. (1986). The force of law: Toward a sociology of the juridical field. Hastings Law Journal, 38, 805.

Bourdieu, P. (1991). Language and symbolic power. Cambridge: Harvard University Press.

Bourdieu, P. (1993). Some properties of fields. In: Sociology in question pp 72-77. Thousand oaks: Sage publishing.

Bourdieu, P. (1996). The rules of art: Genesis and structure of the literary field. Palo Alto: Stanford University Press.

Bourdieu, P., \& Wacquant, L. J. (1992). An invitation to reflexive sociology. Chicago: University of Chicago Press.

Bozoki, A., \& Ishiyama, J. T. (2002). The communist successor parties of central and Eastern Europe. Armonk: M. E. Sharpe. 
Brier, R. (2011). Adam Michnik's understanding of totalitarianism and the west European left: A historical and transnational approach to dissident political thought. East European Politics and Societies, 25(2), $197-218$.

Brubaker, R., \& Cooper, F. (2000). Beyond “identity." Theory and Society, 29(1), 1-47.

Buchholz, L. (2016). What is a global field? Theorizing fields beyond the nation-state. The Sociological Review Monographs, 64(2), 31-60.

Ciobanu, M. (2009). Criminalising the past and reconstructing collective memory: The Romanian truth commission. Europe-Asia Studies, 61(2), 313-336.

Csipke, Z. (2011). The changing significance of the 1956 revolution in post-communist Hungary. Europe-Asia Studies, 63(1), 99-128.

DiMaggio, P. J., \& Powell, W. W. (1983). The iron cage revisited institutional isomorphism and collective rationality in organizational fields. American Sociological Review, 48(2), 147-160.

Enyedi, Z. (2005). The role of agency in cleavage formation. European Journal of Political Research, 44(5), $697-720$.

European Parliament. (2009a). Motion for a Resolution. http:/www.europarl.europa.eu/sides/getDoc. do?type=MOTION\&reference=B6-2009-0164\&language $=\mathrm{EN}$

European Parliament. (2009b). Debates. http:/www.europarl.europa.eu/sides/getDoc.do?pubRef=//EP//TEXT+CRE+20090402+ITEM-010+DOC+XML+V0//EN

European Parliament. (2009c). EP Resolution on European Conscience and Totalitarianism. https://www. europarl.europa.eu/sides/getDoc.do?pubRef=-//EP//TEXT+TA+P6-TA-2009-0213+0+DOC+XML+V0 //EN

European Parliament. (2019). Importance of European remembrance for the future of Europe. http://www. europarl.europa.eu/doceo/document/TA-9-2019-0021_EN.html

Eyal, G. (2013). Spaces between fields. In P. S. Gorski (Ed.), Bourdieu and Historical Analysis (pp. 158-182). Durham: Duke University press.

Eyal, G., Szelenyi, I., \& Townsley, E. (1997). The theory of post-communist managerialism. New Left Review, 1(222), 60.

Fligstein, N. (2001). Social skill and the theory of fields. Sociological Theory, 19(2), 105-125.

Gascón Barberá, M. (2019). Romanian Court Rules Basescu Was Securitate Informer. Balkan Insight. https://balkaninsight.com/2019/09/20/romanian-court-rules-basescuwas-securitate-informer/

Georgakakis, D., \& Rowell, J. (2013). The field of eurocracy: Mapping EU actors and professionals. Dordrecht: Springer.

Hamvay, P. (2015). Meet Mária Schmidt, Fidesz's official historian. Budapest Beacon. https://budapestbeacon.com/meet-maria-schmidt-fideszs-official-historian/. Accessed 28 September 2017.

Hashim, S. M. (2002). Shadows of the past: Successor parties in the polish, Hungarian, and Russian transitions. Problems of Post-Communism, 49(3), 42-58.

Hogea, A. (2010). Coming to terms with the communist past in Romania: An analysis of the political and media discourse concerning the Tismăneanu report. Studies of Transition States and Societies, 2(2), 16-30.

Horne, C. M. (2017). Building trust and democracy: Transitional justice in post-communist countries. Oxford: Oxford University Press.

Hyperliteratura. (2013). Interviu cu Vasile Ernu: "Elita noastră este foarte cuminte, deloc curajoasă, şi iubitoare de a sluji diverse dregătorii". Hyperliteratura. https://hyperliteratura.ro/interviu-vasile-ernu/ . Accessed 28 September 2017.

Iacob, B. (2015). The Romanian communist past and the entrapment of polemics. In B. Iacob \& V. Tismaneanu (Eds.), Remembrance, History, and Justice: Coming to terms with traumatic pasts in democratic societies (pp. 417-474). Budapest: Central European University press.

Jelin, E. (2003). State repression and the labors of memory (Vol. 18). Minneapolis: University of Minnesota Press.

Kattago, S. (2009). Agreeing to disagree on the legacies of recent history: Memory, pluralism and Europe after 1989. European Journal of Social Theory, 12(3), 375-395.

Kiss, C. (2006). The misuses of manipulation: The failure of transitional justice in post-communist Hungary. Europe-Asia Studies, 58(6), 925-940.

Kiss, C. (2015). Divided memory in Hungary: The house of terror and the lack of a left-wing narrative. In S. Mitroiu (Ed.), Life Writing and Politics of Memory in Eastern Europe (pp. 242-259). Dordrecht: Springer.

Kopeček, M. (2012). Human rights facing a National Past: Dissident "civic patriotism" and the return of history in east Central Europe, 1968-1989. Geschichte und Gesellschaft, 38(4), 573-602. 
Laignel-Lavastine, A. (2004). Fascism and communism in Romania: The comparative stakes and uses. In H. Rousso \& R. J. Golsan (Eds.), Stalinism and Nazism: History and memory compared. Lincoln and London: University of Nebraska Press.

Leggewie, C. (2010). Seven circles of European memory. Cultural Memories, pp. 1-29.

Levy, D. (2010). Changing temporalities and the internationalization of memory cultures. Memory and the future: Transnational politics, ethics and society (pp 15-30). London: Palgrave Macmillan.

Littoz-Monnet, A. (2012). The EU politics of remembrance: Can Europeans remember together? West European Politics, 35(5), 1182-1202.

Mälksoo, M. (2009). The memory politics of becoming European: The east European subalterns and the collective memory of Europe. European Journal of International Relations, 15(4), 653-680.

Mark, J. (2010). The unfinished revolution: Making sense of the communist past in Central-Eastern Europe. New Haven: Yale University Press.

Martin, J. L., \& Gregg, F. (2015). Was Bourdieu a field theorist? In M. Hilgers \& E. Mangez (Eds.), Bourdieu's Theory of Social Fields: Concepts and Applications (pp. 39-61). London: Routledge.

McMahon, C. (2019). Victor Orban Adviser Maria Schmidt: “Orban and Trump are like Twins.” Gateway Pundit. https:/www.thegatewaypundit.com/2019/06/victor-orban-adviser-maria-schmidt-orban-andtrump-are-like-twins/

Medvetz, T. (2012). Think tanks in America. Chicago: University of Chicago Press.

Michnik, A., \& Dulzin, A. (2002). Mantra: Rather than discourse. Common Knowledge, 8(3), 516-525.

Michnik, A., \& Havel, V. (1993). Justice or revenge? Journal of Democracy, 4(1), 20-27.

Musiał, F. (2012). Życiorys: Janusz Marek Kurtyka (1960-2010). Janusz Kurtyka. http://januszkurtyka. info/index.php/zyciorys . Accessed 28 September 2017.

Nalepa, M. (2010). Skeletons in the closet: Transitional justice in post-communist Europe. Cambridge: Cambridge University Press.

Olick, J. K. (2006). Products, processes, and practices: A non-reificatory approach to collective memory. Biblical Theology Bulletin, 36(1), 5-14.

Origo. (2002). 41-től 60-ig. https://www.origo.hu/gazdasag/hirek/2002111541tol.html

Petrescu, C., \& Petrescu, D. (2007). Mastering vs. coming to terms with the past: A critical analysis of postcommunist Romanian historiography. In S. Antohi, B. Trencsényi, \& P. Apor (Eds.), Narratives Unbound: Historical Studies in Post-Communist Eastern Europe (pp. 311-408). Budapest: Central European University press.

Platform. (2012a). Bulgarian committee COMDOS presently not welcome to join the Platform of European memory and conscience. Platform of European Memory and Conscience. https://www. memoryandconscience.eu/2013/11/17/presentations-of-the-international-travelling-exhibitiontotalitarianism-in-europe/. Accessed 29 September 2017.

Platform. (2012b). Totalitarianism in Europe: Fascism-Nazism-Communism. Platform of European Memory and Conscience. http:/www.memoryandconscience.eu/wp-content/uploads/2014/01 /Totalitarianism_in_Europe_update_20141.pdf. Accessed 29 September 2017.

Platform. (2013). Presentations of the international travelling exhibition "Totalitarianism in Europe." Platform of European Memory and Conscience. https://www.memoryandconscience.eu/2013/11/17/presentationsof-the-international-travelling-exhibition-totalitarianism-in-europe/ . Accessed 29 September 2017.

Platform. (2014). Platform suspends Membership of Czech Institute for the Study of Totalitarian Regimes. Platform of European Memory and Conscience. https:/www.memoryandconscience.eu/2014/01/14 /platform-suspends-membership-of-czech-institute-for-the-study-of-totalitarian-regimes/ . Accessed 29 September 2017.

Poenaru, F. (2013). Contesting illusions: History and intellectual class struggle in post-communist Romania. Central European University, Department of Sociology and Social Anthroplogy, Budapest, Hungary.

Rees, A. (2010). Managing the history of the past in the former communist states. In M. Pakier \& B. Stråth (Eds.), A European memory? Contested histories and politics of remembrance. New York: Berghahn Books.

Schmidt, M. (2009). Gyurcsány lenullázta a baloldalt, új korszak előtt állunk. HVG. https://hvg. hu/velemeny/20090625_schmidtmaria_gyurcsany_rendszervaltas

Schmidt-Wellenburg, C. (2017). Europeanisation, stateness, and professions: What role do economic expertise and economic experts play in European political integration? European Journal of Cultural and Political Sociology, 4(4), 430-456.

Stan, L. (2002). Moral cleansing Romanian style. Problems of Post-Communism, 49(4), 52-62.

Stan, M., \& Tismăneanu, V. (2015). Coming to terms with the communist past. P. 23 In Post-Communist Romania at Twenty-Five: Linking Past, Present, and Future. Lanham: Lexington books. 
Stark, D. (2009). The sense of dissonance: Accounts of worth in economic life. Princeton: Princeton University Press.

Steinmetz, G. (2008). The colonial state as a social field: Ethnographic capital and native policy in the German overseas empire before 1914. American Sociological Review, 73(4), 589-612.

Steinmetz, G. (2011). Bourdieu, historicity, and historical sociology. Cultural Sociology, 5(1), 45-66.

Stone, L. (1971). Prosopography. Daedalus, 100, 46-79.

Tănăsoiu, C. (2008). Intellectuals and post-communist politics in Romania: An analysis of public discourse, 1990-2000. East European Politics and Societies, 22(1), 80-113.

Tileagă, C. (2012). Communism in retrospect: The rhetoric of historical representation and writing the collective memory of recent past. Memory Studies, 5(4), 462-478.

Tismaneanu, V. (1993). The quasi-revolution and its discontents: Emerging political pluralism in postCeauşescu Romania. East European Politics and Societies, 7(2), 309-348.

Tismaneanu, V. (2003). Stalinism for all seasons: A political history of Romanian communism (Vol. 11). Berkeley: University of California Press.

Trencsényi, B., \& Apor, P. (2007). Fine-tuning the polyphonic past: Hungarian historical writing in the 1990s. In S. Antohi, B. Trencsényi, \& P. Apor (Eds.), Narratives Unbound: Historical Studies in PostCommunist Eastern Europe (pp. 311-408). Budapest: Central European University press.

Troebst, S. (2010). Halecki revisited: Europe's conflicting cultures of remembrance. In M. Pakier \& B. Stråth (Eds.), A European memory? Contested histories and politics of remembrance. New York: Berghahn Books.

Verovšek, P. J. (2015). Expanding Europe through memory: The shifting content of the ever-salient past. Millennium, 43(2), 531-550.

Wacquant, L. (2016). A concise genealogy and anatomy of habitus. The Sociological Review, 64(1), 64-72. Waisová, Š., \& Piknerová, L. (2012). Twenty years after: Dissident tradition in Czech foreign policy matters. East European Politics and Societies, 26(1), 162-188.

Publisher's note Springer Nature remains neutral with regard to jurisdictional claims in published maps and institutional affiliations.

Zoltan Dujisin is a Marie Curie Leading Fellow at Erasmus University Rotterdam. He obtained his PhD in sociology at Columbia University in New York and previously received an MPhil in political science from Central European University in Budapest, where he conducted most of the field research for this article. He currently investigates the networks of expertise informing journalistic constructions of disinformation as well as their effect on journalists' professional identities. 